\title{
Pengaruh Model Pembelajaran Examples Non Examples terhadap Kemampuan Menulis Surat Resmi pada Siswa Kelas VIII SMP Negeri 1 Bojong, Pandeglang
}

\author{
Sopyan Sauri ${ }^{1}$ \\ ${ }^{1}$ Universitas Mathla'ul Anwar Banten
}

\begin{tabular}{|c|c|}
\hline ARTICLE INFO & ABSTRACT \\
\hline $\begin{array}{l}\text { Article History: } \\
\text { Received 18.07.2018 } \\
\text { Received in revised } \\
\text { form } 14.09 .2018 \\
\text { Accepted } 19.09 .2018 \\
\text { Available online } \\
\text { 27.09.2018 }\end{array}$ & $\begin{array}{l}\text { The purpose of this study is to investigate the influence of examples non examples } \\
\text { learning model on the ability to write an official letter of eighth grade students of } \\
\text { SMP Negeri } 1 \text { Bojong Academic Year 2015/2016. This study uses an experimental } \\
\text { method conducted from April to May, white a population of this research is all class } \\
\text { VIII SMP Negeri } 1 \text { Bojong students in the academic year } 2015 / 2016 \text {. The sample } \\
\text { technique used is cluster random sampling, so that from the sampling technique the } \\
\text { sample obtained is the class VIII B and class VIII A. Each of them is } 28 \text { students. So } \\
\text { the overall sample is } 56 \text { samples. The VIII B class was given treatment in the form of } \\
\text { the use of examples non examples learning model. Whereas class VIII A used an } \\
\text { expository learning model in the learning process. Based on the results of data } \\
\text { processing, it was obtained an illustration that the students' official letter writing skill } \\
\text { using the examples non examples learning model in the experimental class was quite } \\
\text { good. It could be seen from } 28 \text { students, there are } 20 \text { students or } 71.41 \% \text { who get score } \\
\text { more than } 68 \text {. While the rest } 8 \text { students or } 28.56 \% \text { got a score between } 50-67 \text { by an } \\
\text { average score of } 71.78 ; \text { highest value } 83 \text {, and lowest value } 50 \text {. While the students' } \\
\text { official letter writing skill using the expository learning model is not good. As } \\
\text { illustrated by } 28 \text { students who were sampled, there were } 10 \text { students or } 35.7 \% \text { got } \\
\text { more than } 54 \text {. While the remaining } 18 \text { students or } 64.27 \% \text { got scores between } 30-53 \text {. } \\
\text { by an average score of } 51.35 \text {; the highest value is } 64 \text {, and the lowest value is } 30 \text {. Thus, } \\
\text { it can be concluded that there is a positive influence on the use of examples non } \\
\text { examples learning model on the ability to write an official letter for eighth grade } \\
\text { students of SMP Negeri } 1 \text { Bojong academic year } 2015 / 2016 \text {. }\end{array}$ \\
\hline
\end{tabular}

Keywords: Examples Non Examples, Official Letter Writing Skills.

DOI: $10.30653 / 006.201811 .4$

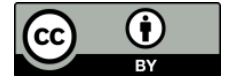

This is an open access article distributed under the terms of the Creative Commons Attribution 4.0 International License, which permits unrestricted use, distribution, and reproduction in any medium, provided the original work is properly cited. ๑) 2018 Sopyan Sauri.

\section{PENDAHULUAN}

Keterampilan berbahasa dipelajari agar manusia mampu berkomunikasi. Tarigan (2008: 19) menyatakan bahwa komunkasi adalah suatu proses pengiriman dan penerimaaan pesan-pesan yang pasti terjadi sewaktu-waktu bila manusia atau binatang 
ingin berkenalan dan berhubungan satu sama lain. Manusia melakukan komunikasi dengan sesamanya melalui dua cara yang pertama komunikasi secara langsung dan yang kedua komunikasi secara tidak langsung. Komunikasi secara langsung, manusia berkomunikasi secara tatap muka dalam satu waktu dengan menggunakan media bahasa. Komunikasi secara tidak langsung adalah komunikasi yang dilakukan dengan menggunakan media tertentu seperti internet, faximail, dan surat.

Keterampilan berbahasa yang harus dikuasai dalam pembelajaran bahasa Indonesia adalah keterampilan menyimak, keterampilan berbicara, keterampilan membaca, dan keterampilan menulis. Untuk memperoleh keterampilan berbahasa biasanya dimulai dengan hubungan urutan yang sistematis. Mula-mula seseorang belajar menyimak, setelah terampil menyimak maka akan diaplikasikan dengan berbicara, setelah itu keterampilan membaca dan selanjutnya keterampilan menulislah yang akan dipelajari. Dengan kata lain keterampilan menyimak, menjadi syarat untuk dapat menguasai keterampilan berbicara, keterampilan berbicara juga menjadi syarat dalam menguasai keterampilan membaca dan keterampilan membaca menjadi syarat dalam menguasai keterampilan menulis. Keempat keterampilan berbahasa tersebut satu sama lainya saling berkaitan membantuk satu kesatuan yang disebut catur tunggal.

Dari keempat keterampilan berbahasa tersebut, keteramplan menulis sering dipandang sebagai keterampilan yang paling sulit dikuasai. White dan Arndut dalam Hoerudin dan Chodijah (2007:3) menyatakan bahwa menulis bukanlah urusan sederhana menuliskan bahasa ke dalam lambang tulisan; menulis merupakan suatu proses berfikir dalam kebenaran yang dimilikinya. Pada kenyataanya memang tidak gampang untuk menguasai keterampilan menulis karena selain harus menguasai tiga keterapilan sebelumnya yang menjadi prasyarat menguasai keterampilan menulis juga harus menguasai kemampuan-kemampuan yang lainya seperti pengunaan ejaan, pemilihan kata, pengkalimatan dan pewacanaan.

Tarigan (2008:3) menyatakan bahwa menulis adalah suatu keterampilan berbahasa yang diperguakan untuk komunikasi secara tidak langsung. Sedangkan Suparno dan Yunus (2014:1.3) menyatakan bahwa menulis didefinisikan sebagai suatu kegiatan menyampaikan pesan dengan menggunakan bahasa tulis sebagai medianya. Jelasnya bahwa fungsi utama dari menulis adalah untuk menyampaikan pesan atau informasi dalam komunikasi secara tidak langsung dengan orang lain.

Menulis surat merupakan salah satu kemampuan yang harus dimiliki oleh siswa. Itu penting sebagai sarana untuk berkomuniksi tidak langsung dengan sesamanya.Suparno dan Yunus (2014:6.6) menyatakan bahwa surat adalah salah satu alat komunikasi tertulis untuk menyampaikan suatu pesan dari seseorang/intansi kepada satu pihak atau suatu instansi atau suatu organisasi/instansi kepada orang, pihak atau organisasi/instansi lain. Komunikasi tidak langsung dengan menggunakan surat di pandang sebagai alat komunikasi paling efisien, efektif, ekonomis, dan praktis, sehingga banyak digunakan oleh masyarakat.

Menulis surat tidak menjadi suatu masalah ketika yang kita tulis adalah surat pribadi. Karena surat pribadi tidak mempunyai ketentuan-ketentuan yang harus diterapkan dalam penulisannya. Surat pribadi adalah surat yang berisi masalah pribadi yang ditujukan kepada keluarga, teman, dan kenalan. Sehingga bahasa yang digunakan dalam surat pribadi bersipat akrab dan santai yang tidak harus patuh dengan tata baku bahasa indonesia. Namun ketika yang ditulisnya itu adalah surat resmi maka kesulitan pun akan menghampiri, karena dalam surat resmi terdapat banyak ketentuan-ketentuan yang harus diterapkan dalam penulisannya.Soedjito dan Solchan (2016:14) menyatakan 
bahwa Surat resmi adalah surat yang berisi masalah kedinasan/administrasi pemerintah, surat resmi hanya dibuat oleh instansi pemerintah, dapat dikirim kepada semua pihak yang memiliki hubungan dengan instansi tersebut.

Ketentuan-ketentuan yang harus diterapkan dalam penulisan surat resmi yang terkadang membuat siswa kesulitan dalam menulis surat resmi adalah penggunaan bahasa surat. Bahasa yang diguakan dalam surat resmi adalah ragam resmi. Secara garis besar ragam resmi dalam surat dapat dibagi menjadi dua yaitu (1). Bahasa baku adalah bahasa yang diakui benar menurut kaidah yang sudah ditentukan dan dilazimkan. (2). Bahasa efektif adalah bahasa yang tidak berbelit-belit langsung menuju sasarannya. Bahasa efektif adalah bahasa yang sederhana, ringkas, jelas, sopan dan menarik. Kurangnya pengetahuan mengenai bahasa baku dan bahasa efektif yang pada akhirnya menyulitkan dalam membuat surat.

Selain itu hal yang terkadang membingungkan siswa dalam menulis surat resmi adalah bentuk atau format surat yang sudah ditentukan. Bentuk surat tersebut merupakan variasi surat yang menyebabkan timbulnya macam-macam bentuk surat. Finoza dalam Suparno dan Yunus (2014:6.11) menyatakan bahwa bentuk surat adalah pola surat yang telah ditentukan tata letak atau posisi bagain-bagian surat. Secara garis besar bentuk/format surat resmi dibagi kedalam lima bentuk yaitu (1) bentuk lurus penuh, (2) bentuk lurus, (3) bentuk setengah lurus, (4) bentuk resmi Indonesia lama, (5) bentuk resmi Indonesia baru.

Ditambah lagi bagian-bagian surat merupakan struktur yang membangun sebuah surat. Bagian-bagian ini harus ada yang disusun dengan posisi tertentu sesuai dengan bentuk surat yang digunakan. Setiap bagian surat mempunyai fungsi masing masing dan merupakan pembeda dari bentuk surat pribadi dan bentuk karangan yang lain. Secara umum bagian-bagian surat terdiri dari (1) kepala Surat, (2), nomor surat, (3) Tanggal, Bulan, dan Tahun surat, (4) lampiran, (5) hal/prihal, (6) alamat surat, (7) salam pembuka, (8) isi surat, (9) salam penutup, (10) tembusan.

Dalam hal ini pendidik harus berusaha semaksimal mungkin menyampaikan materi tentang surat resmi agar siswa tidak keliru, dan tidak bingung. Dengan menggunakan model yang dianggap relevan dengan pembelajaran ini. Komalasari (2011:57) menyatakan bahwa model pembelajaran pada dasarnya merupakan suatu bentuk pembelajaran yang tergambar dari awal sampai akhir yang disajikan secara khas oleh guru. Sedangkan Uno dan Mohamad (2011:7) menyatakan bahwa model pembelajaran didefinisikan sebagai suatu cara yang digunakan guru dalam menjalankan fungsinya dan merupakan alat untuk mencapai tujuan pembelajaran. Pemilihan model pembelajaran harus disesuaikan dengan materi yang akan diajarkan. Tidak semua model dapat digunakan pada semua jenis materi pembelajaran. Itu disebabkan karena masing-masing materi pembelajaran mempunyai karakteristik tersendiri. Selain itu kriteria ketuntasan minimal pada setiap materi pun berbeda.

Penulis beranggapan bahwa model yang tepat untuk pembelajaran menulis surat resmi adalah model pembelajaran examples non examples. Komalasari (2011:61) menyatakan bahwa model pembelajaran examples non examples merupakan cara membelajarkan siswa terhadap permasalahan yang ada disekitarnya melalui analisis contoh-contoh berupa gambar-gambar/foto/kasus yang bermuatan masalah. Sedangkan Hamdani (2011:90) menyatakan bahwa model pembelajaran examples non examples adalah model belajar yag menggunakan contoh contoh. Model ini merupakan model pembelajaran yang mamanfaatkan media gambar dalam proses pembelajarannya dengan langsung menghadirkan contoh nyata sehingga akan menghilangkan verbalisme pada 
anak. Dengan media gambar dan contoh-contoh siswa diarahkan untuk mengidentifikasi masalah, mencari alternatif pemecahan masalah, dan menentukan cara pemecahan masalah yang paling efektif dengan melihat contoh.

Contoh yang disuguhkan kepada siswa dengan menggunakan model pembelajaran ini terbagi kedalam dua contoh. Yang pertama examples memberikan gambar/contoh yang berhubungan dengan materi yang diajarkan. Dan yang kedua non examples memberikan gambaran akan sesuatu yang bukan contoh dari materi yang dibahas yang dimungkinkan masih terdapat bagian yang merupakan satu karakter dari materi yang diajarkan.

Pemberian dua contoh yang berbeda tersebut akan menambah wawasan terhadap siswa tentang perbedaan dua konsep. Siswa akan mengeksplorasi contoh yang diberikan secara bersamaaan dalam satu waktu. Dan contoh tersebut mempunyai konsep yang berbeda/berlawanan sehingga akan menimbulkan pemikiran kritis pada diri siswa. Contoh yang diperlihatkan kepada siwa, selanjutnya siswa disarankan menganalisis contoh tersebut. Dan membuat sebuah bentuk deskripsi singkat mengenai apa yang ada dalam contoh yang diperlihatkan. Sehingga pendidik tidak terlalu dominan dalam pembelajaran ini.

Examples non examples dikatakan model pembelajaran aktif, karena selain siswa aktif dalam melihat dan memperhatikan contoh yang diperlihatkan juga aktif dalam berinteraksi dengan teman sesamanya yaitu melalui diskusi kelompok. Sehingga selain melatih siswa berpikir kritis, model pembelajaran ini juga melatih siswa untuk aktif bersosialisasi, bertukar pikiran dan menyampaikan pendapat dalam sebuah kelompok kecil.

Model pembelajaran ini dalam penggunaannya biasanya dilaksanakan pada kelas tinggi. Karna kelas tinggi daya fikir dan cara belajar peserta didiknya pun sudah kritis. Sehigga akan cocok ketika menganalisis sebuah masalah. Namun dapat juga digunakan pada kelas rendah dengan mempertimbangkan aspek psikologis dan tingkat perkembangan siswa tingkat rendah seperti kemampuan berbahasa tulis dan lisan, kemampuan analisis ringan dan kemampuan berinteraksi dengan siswa lainnya.

Dalam pelaksanaannya model pembelajaran examples non examples ini dapat menggunakan media gambar melalui infocus, proyektor atau yang paling sederhana pendidik menempelkan poster. Gambar dari contoh tersebut haruslah dapat dilihat dengan jelas oleh semua siswa sampai yang ada di belakang. Sehingga siswa tidak akan kesulitan dalam menganalisis sebuah contoh tersebut.

Model pembelajaran examples non examples merupakan taktik yang dapat digunakan untuk mengajarkan definisi konsep. Konsep biasanya dipelajari melalui dua cara yaitu melalui sebuah pengamatan yang biasanya dilakukan di luar sekolah dan yang kedua konsep dipelajari melalui definisi konsep itu senidri. Sehingga peserta didik sering kesulitan untuk memahami konsep tersebut. Tetapi dengan menggunakan model examples non examples peserta didik tidak akan kebingungan lagi karena definisi konsep adalah fisiknya.

Untuk mengaplikasikan model pembelajaran examples non examples ke dalam sebuah proses pembelajaran langkah-langkahnya adalah sebagai berikut:

1) Guru mempersiapkan gambar-gambar sesuai dengan tujuan pembelajaran

2) Guru menempelkan gambar di papan atau ditayangkan melalui OHP/Proyektor/ hanya berupa slide kertas. 
3) Guru memberi petunjuk dan memberi kesempatan pada siswa untuk memperhatikan/menganalisa gambar

4) Melalui diskusi kelompok 2-3 orang siswa, hasil diskusi dari analisa gambar tersebut dicatat pada kertas

5) Tiap kelompok diberi kesempatan membacakan hasil diskusinya

6) Mulai dari komentar/hasil diskusi siswa, guru mulai menjelaskan materi sesuai tujuan yang ingin dicapai

7) Kesimpulan

Berdasarkan uraian di atas penulis terdorong untuk melakukan penelitian tentang Pengaruh Model Pembelajaran Examples Non Examples Terhadap Kemampuan Menulis Surat Resmi Pada Siswa Kelas VIII SMPN 1 Bojong.

\section{METODE}

Penelitian ini bertujuan untuk mendapatkan gambaran pengaruh model pembelajaran Examples Non Examples terhadap kemempuan menulis surat resmi siswa kelas vii smpn 1 bojong. Metode penelitian yang digunakan dalam penelitian ini adalah metode eksperimen. Sugiyono (2012:72) menyatakan bahwa metode eksperimen adalah metode penelitian yang digunakan untuk mencari pengaruh perlakuan tertentu terhadap yang lain dalam kondisi yang terkendalikan. Pengambilan sampel dalam penelitian ini menggunakan teknik cluster random sampling. Untuk menentukan sampelnya peneliti merujuk kepada pendapat Arikunto (2010:112) menyatakan bahwa apabila subjeknya kurang dari 100, lebih baik diambil semua sehingga penelitiannya merupakan penelitian populasi. Selanjutnya jika jumlah subjeknya besar dapat diambil antara $10-15 \%$, atau $20-$ $25 \%$ atau lebih. Untuk itu dari lima kelas yang menjadi populasi diambil sampelnya 2 (Dua) kelas sebanyak 56 siswa. Kelas pertama di berikan perlakuan dengan menggunakan model pembelajaran examples non examples sebagai kelas eksperimen sebanyak 28 siswa. Sedangkan kelas kedua sebagai kelas kontrol sebanyak 28 siswa dengan menggunakan model pembelajaran exspositori. Desain eksperimen seperti pada Tabel 1.

Tabel 1. Desain Penelitian

\begin{tabular}{lll}
\hline Kelompok & Perlakuan & Tes akhir \\
\hline Eksperimen & $\mathrm{X}$ & $\mathrm{T} 2$ \\
\hline Kontrol & 0 & $\mathrm{~T} 2$ \\
\hline
\end{tabular}

\section{Keterangan}

X : Perlakuan yang diberikan kepada kelas eksperimen berupa penggunaan model pembelajaran examples non examples.

0 : Perlakuan yang diberikan kepada kelas kontrol berupa penggunaan model pembelajaran ekspositori

T2 : Hasil belajar berupa tes akhir dari kelas eksperiman dan kelas kontrol 


\section{PEMBAHASAN}

\section{Temuan Tentang Kemampuan Menulis Surat Resmi dengan Model Pembelajaran Examples Non Examples}

Berdasarkan hasil penelitian tes kemampuan menulis surat resmi dengan menggunakan model pembelajaran examples non examples diperoleh rentangan skor antara $50-83$ dengan rentang skor atau range (r) sebesar 33. Dengan banyak kelas (K) diambil dari prhitungan $1+3,3 \log 28=5,77$ (dibulatkan 6). Dan panjang kelas $33: 6=5,5$ (dibulatkan 6). Selain itu dari perhitungan statistik didapatkan pula nilai rata-rata (mean) 71,78; median (Me) 74,04; dan modus 76,26; serta simpangan baku sebesar 8,23.

Selanjutnya penulis akan sajikan tebel distribusi frekuensi kelas eksperimen yaitu kemempuan menulis surat resmi dengan menggunakan model pembelajaran examples non examples.

Tabel 2. Distribusi Frekuensi Kelas Eksperimen

\begin{tabular}{llll}
\hline No & Interval & Frekuensi & Ferkuensi Relatif \\
\hline 1 & $50-55$ & 1 & $3,57 \%$ \\
\hline 2 & $56-61$ & 3 & $10,71 \%$ \\
\hline 3 & $62-67$ & 4 & $14,28 \%$ \\
\hline 4 & $68-73$ & 5 & $17.85 \%$ \\
\hline 5 & $74-79$ & 11 & $39,28 \%$ \\
\hline 6 & $80-85$ & 4 & $14,28 \%$ \\
\hline Jumlah & 28 & $100 \%$ \\
\hline
\end{tabular}

Berdasarkan tabel tersebut diperoleh bahwa tes kemampuan menulis surat resmi siswa menapatkan nilai yang cukup baik. Dari 28 siswa yang menjadi sampel didapat sebanyak 20 siswa atau $71,41 \%$ memperoleh nilai lebih dari 68 . sedangkan sisanya sebanyak 8 siswa atau $28,56 \%$ mendapat nilai antara $50-67$.

Secara rinci dapat digambarkan bahwa sebanyak 8 siswa atau 28,56\% kemampuan menulis surat resmi mendapatkan nilai antara 50 - 67. selain itu yang mendapatkan nilai antara 68 - 73 sebanyak 5 siswa atau 17,85\%. Adapun sebanyak 39,28\% atau 11 siswa mendapatkan nilai antara $74-79$. sedangkan yang mendapatkan nilai $80-85$ sebanyak 4 siswa atau $14,26 \%$.

\section{Temuan Tentang Kemampuan Menulis Surat Resmi Dengan Model Pembelajaran Ekspositori}

Berdasarkan hasil penelitian tes kemampuan menulis surat resmi dengan menggunakan model pembelajaran ekspositori diperoleh rentangan skor antara $30-65$ dengan rentang skor atau range $(r)$ sebesar 34 . Dengan banyak kelas $(K)$ diambil dari prhitungan $1+3,3 \log 28=5,77$ (dibulatkan 6). Dan panjang kelas $34: 6=5,66$ (dibulatkan 6). Selain itu dari perhitngan statistik didapatkan pula nilai rata-rata (mean) 51,35 ; median (Me) 51,81; dan modus 50,73; Serta simpangan baku sebesar 7.79.

Tabel 3 menyajikan distribusi frekuensi kelas kontrol yaitu kemempuan menulis surat resmi dengan menggunakan model pembelajaran ekspositori. 
Tabel 3. Distribusi Frekuensi Kelas Kontrol

\begin{tabular}{llll}
\hline No & Interval & Frekuensi & Frekuensi Relatif \\
\hline 1 & $30-35$ & 1 & 3,57 \\
\hline 2 & $36-41$ & 2 & 7,14 \\
\hline 3 & $42-47$ & 4 & 14,28 \\
\hline 4 & $48-53$ & 11 & 39,28 \\
\hline 5 & $54-59$ & 5 & 17,85 \\
\hline 6 & $60-65$ & 5 & 17,85 \\
\hline Jumlah & 28 & 100 \\
\hline
\end{tabular}

Berdasarkan Tabel 3 diperoleh bahwa tes kemampuan menulis surat resmi siswa mendapatkan nilai yang kurang baik. Dari 28 siswa yang menjadi sampel didapat sebanyak 10 siswa atau 35,7\% memperoleh nilai lebih dari 54. sedangkan sisanya sebanyak 18 siswa atau 64,27\% mendapat nilai antara $30-53$.

Secara rinci dapat digambarkan bahwa sebanyak 3 siswa atau 10,71\% kemampuan menulis surat resmi mendapatkan nilai antara $30-41$. Selain itu yang mendapatkan nilai antara 42 - 53 atau 53,56\% sebanyak 14 siswa. Adapun sebanyak 5 siswa mendapatkan nilai antara $54-59$ atau $17,85 \%$. serta sebanyak $17,85 \%$ atau 5 siswa mendapatkan nilai antara $60-65$.

\section{Pengujian Persyaratan Analisis}

\section{Uji Normalitas}

Uji normalitas dilakukan untuk mengetahui apakah kedua variabel yang digunakan bersifat normal atau tidak. Subana,dkk (2015:123) menyatakan bahwa normalitas sebaran data menjadi sebuah asumsi yang menjadi syarat untuk mementukan jenis statikstik apa yang dipakai dalam penganalisisan selanjutnya. Maksud dari pernyataan di atas adalah ketika sebaran data normal maka peneliti boleh menggunakan teknik statistik parametik, sedangkan apabila data yang dianalisis tidak merupakan sebaran normal, maka peneliti harus mengguakan statistik non parametik. Uji normalitas dilakukan dengan menggunakan Chi kuadrat $\left(\mathrm{X}^{2}\right)$ dengan taraf signifikansi 5\% atau 0,05 dengan kriteria pengujian sebagai berikut:

Jika, $\chi_{\text {hitung }}^{2}>x_{\text {tabel, }}^{2}$, maka data tidak normal

Jika, $\chi_{\text {hitung }}^{2}<x_{\text {tabel }}^{2}$, maka data berdistribusi normal

\section{Uji Normalitas Data Kelas Eksperimen}

Perhitungan uji normalitas data kelas eksperimen hasilnya sebagai berikut:

Berdasarkan perhitungan statistik, diperoleh nilai Chi kuadrat atau, $\chi_{\text {hitung }}^{2}=1,7174$ sedangkan $x_{\text {tabel, }}^{2}$, pada $\alpha(0,05)$ adalah sebesar 7,815. dengan demikian $\chi_{\text {hitung }}^{2}<x_{\text {tabel }}^{2}$, Hal ini berarti data berdistribusi normal.

Untuk lebih jelas perolehan nilai Chi kuadrat, di bawah ini penulis sajikan tabel distribusi normalitas data kelas eksperimen. 
Tabel 4. Distribusi Normalitas Data Kelas Eksperimen

\begin{tabular}{lllllll}
\hline No & Batas kelas & $Z$ & $\begin{array}{l}\text { Luas } \\
0-Z\end{array}$ & $\begin{array}{l}\text { Luas tiap } \\
\text { Kelas Interval }\end{array}$ & Fe & Fo \\
\hline 1 & 49,5 & $-2,70$ & 0,4965 & 0,0209 & 0,5852 & 1 \\
\hline 2 & 55,5 & $-1,79$ & 0,4756 & 0,0831 & 2,3268 & 3 \\
\hline 3 & 61,5 & $-1,24$ & 0,3925 & 0,194 & 5,432 & 4 \\
\hline 4 & 67,5 & $-0,52$ & 0,1985 & 0,1192 & 3,3376 & 5 \\
\hline 5 & 73,3 & 0,20 & 0,0793 & 0,4031 & 11,2868 & 11 \\
\hline 6 & 79,5 & 0,93 & 0,3238 & 0,1277 & 3,5756 & 4 \\
\hline & 85,5 & 1,66 & 0,4515 & & & \\
\hline
\end{tabular}

\section{Uji Normalitas Data Kontrol}

Perhitungan uji normalitas data kelas kontrol hasilnya sebagai berikut:

Berdasarkan perhitungan statistik, diperoleh nilai Chi kuadrat atau $\chi_{\text {hitung }}^{2}=6,02$ sedangkan $x_{\text {tabel, }}^{2}$, pada $\alpha(0,05)$ adalah sebesar 7,815. dengan demikian $\chi_{\text {hitung }}^{2}<\chi_{\text {tabel, }}^{2}$, Hal ini berarti dar berdistribusi normal.

Untuk lebih jelas perolehan nilai Chi kuadrat, di bawah ini penulis sajikan tabel distribusi normalitas data kelas kontrol.

Tabel 5. Distribusi Normalitas Data Kelas Kontrol

\begin{tabular}{lllllll}
\hline No & Batas kelas & $Z$ & $\begin{array}{l}\text { Luas } \\
0-Z\end{array}$ & $\begin{array}{l}\text { Luas tiap } \\
\text { Kelas interval }\end{array}$ & Fe & Fo \\
\hline 1 & 29,5 & $-0,80$ & 0,2881 & 0,1907 & 5,3396 & 1 \\
\hline 2 & 35,5 & $-2,03$ & 0,4788 & 0,0826 & 2,3128 & 2 \\
\hline 3 & 41,5 & $-1,26$ & 0,3962 & 0,2083 & 5,8324 & 4 \\
\hline 4 & 47,5 & $-0,49$ & 0,1879 & 0,2943 & 8,2404 & 11 \\
\hline 5 & 53,5 & $-0,27$ & 0,1046 & 0,2374 & 6,6472 & 5 \\
\hline 6 & 59,5 & 1,02 & 0,3438 & 0,1211 & 3,3908 & 5 \\
\hline & 65,5 & 1,81 & 0,4649 & & & \\
\hline & & & & & \\
\hline
\end{tabular}

\section{Uji Homogenitas}

Setelah diketahui normal tidaknya sebaran data kemampuan menulis surat resmi baik pada kelas eksperimen maupun kelas kontrol. Maka selanjutnya dilakukan uji homogenitas data. Arikunto (2010:289) menyatakan bahwa uji homogenitas (kesamaan) beberapa bagian sampel, yakni seragam tidaknya varians sampel-sampel yaang diambil dari populasi yang sama. Untuk menguji homogenitas penulis menggunakan rumus varians terkecil dan varians terbesar, dengan kriteria sebagai berikut:

Jika $F_{\text {hitung }} \leq F_{\text {tabel }}$, homogen

Jika $F_{\text {hitung }}>F_{\text {tabel }}$, tidak homogen

Hasil perhitungan diperoleh $F_{\text {hitung } \leq F_{\text {tabel }}}$ atau 1,116 $<1,892$, maka data yang diperoleh homogen. 


\section{Pengujian Hipotesis}

Dalam penelitian ini hipotesis dirumuskan dalam bentuk hipotesis penelitian yang menyatakan bahwa terdapat pengaruh penggunaan model pembelajaran examples non examples terhadap kemampuan menulis surat resmi. Setelah dilakukan penelitian dari hasil analisis data didapatkan nilai rata-rata siswa dengan menggunakan model pembelajaran examples non examples yaitu 71,78 , dengan nilai terendah 50 dan nilai tertinggi 83. Sedangkan nilai rata-rata dengan menggunakan model pembelajaran ekspositori yaitu 51,35, dengan nilai terendah 30 dan nilai tertinggi 64 .

Jika dilihat dari nilai rata-ratanya, kemampuan menulis surat resmi siswa dengan menggunakan model pembelajaran examples non examples memperoleh nilai lebih tinggi bila dibandingkan dengan menggunakan model pembelajaran ekspositori. Dan diinterpretasikan dengan uji $\mathrm{t}$ maka nilai $\mathrm{t}$ hitung $=9,82$. sedangkan $\mathrm{t}$ tabel pada tingkat kepercayaan 0,95 dengan derajat kebebasan 54 diperoleh nilai 1,674. dengan kriteria pengujian sebagai berikut:

$t_{\text {hitung }}>t_{\text {tabel }}$

Jika $t_{\text {hitung }}<t_{\text {tabel }}$ Ho diterima

Jika $t_{\text {hitung }}>t_{\text {tabel }}$, Ho ditolak

Dengan demikian Ho ditolak dan H1 diterima, maka terdapat pengaruh penggunaan model pembelajaran examples non examples terhadap kemampuan manuli surat resmi.

\section{SIMPULAN}

Berdasarkan data nilai tes kemampuan menulis surat resmi pada siswa kelas eksperimen, dengan model pembelajaran examples non examples cukup baik. Hal ini ditunjukan dari 28 siswa yang menjadi sampel didapat sebanyak 20 siswa atau $71,41 \%$ memperoleh nilai lebih dari 68. sedangkan sisanya sebanyak 8 siswa atau $28,56 \%$ mendapat nilai antara 50 - 67. dengan rata-rata nilai 71,78; dengan nilai terendah 50 dan tertinggi 83; modus 76,26; median 74,04 serta standar deviasi sebesar 8,23.

Data nilai tes kemampuan menulis surat resmi pada kelas kontrol dengan menggunakan model pembelajaran ekspositori kurang baik. Hal ini terlihat dari 28 siswa yang menjadi sampel didapat sebanyak 10 siswa atau 35,7\% memperoleh nilai lebih dari 54. sedangkan sisanya sebanyak 18 siswa atau $64,27 \%$ mendapat nilai antara $30-53$. dengan mendapatkan nilai rata-rata 51,35; nilai terendah 30 dan nilai tertinggi 64; modus 50,75; dan median 51,81 serta standar deviasi 7,79.

Terdapat pengaruh penggunaan model pembelajaran examples non examples terhadap kemampuan menulis surat resmi siswa. Hal ini ditunjukan dari data hasil analisis dengan menggunakan rumus uji t, diperoleh $t_{\text {hitung }} 9$ 9,82. Dan untuk taraf signifikansi 0,95 dengan derajat kebebasan 54 diperoleh $t_{\text {tabel }}$ sebesar 1,674. Jika $t_{\text {hitung }}$ lebih besar daripada $t_{\text {tabel }}$ maka hipotesis nol (Ho) ditolak dan H1 diterima. Maka terbukti bahwa terdapat pengaruh positif penggunaan model pembelajaran examples non examples terhadap kemampaun menulis surat resmi. 


\section{REFERENSI}

Arikunto, S. (2010). Prosedur penelitian. Jakarta: Rineka Cipta.

Hamdani. (2011). Strategi belajar mengajar. Bandung: Pusaka Setia.

Hoerudin, C. W., \& Chodijah, S. (2007). Mengasah keterampilan menulis. Bandung: Insan Mandiri.

Komalasari, K. (2011). Pembelajaran kontekstual konsep dan aplikasi. Bandung: Refika Aditama.

Riduwan. (2011). Dasar-dasar statistik. Bandung: Alfabeta.

Rusman. (2012). Model-model pembelajaran. Jakarta: Raja Grafindo Persada.

Soedjito, \& Solchan, T. W. (2016). Surat menyurat resmi bahasa Indonesia. Bandung: Remaja Rosdakarya.

Subana, Rahadi, M., \& Sudrajat. (2015). Statistik pendidikan. Bandung: Pusaka Setia.

Subana, \& Sunarti. (2009). Strategi belajar mengajar bahasa Indonesia. Bandung: Pusaka Setia.

Sugiyono. (2012). Metode penelitian kuantitatif, kualitatif, dan RED. Bandung: Alfabeta.

Suparno, \& Yunus, M. (2014). Keterampilan dasar menulis. Jakarta: Universitas Terbuka.

Tarigan, H. G. (2008). Menulis sebagai suatu keterampilan berbahasa. Bandung: Angkasa.

Uno, H. B., \& Mohamad, N. (2011). Belajar dengan pendekatan PAILKEM. Jakarta: Bumi Aksara. 